\title{
Further Studies on the Molecular Systematics of Biomphalaria Snails from Brazil
}

\author{
Teofânia HDA Vidigal/*, Roberta Lima Caldeira, Andrew JG Simpson**, \\ Omar S Carvalho/ ${ }^{+}$
}

\begin{abstract}
Centro de Pesquisas René Rachou-Fiocruz, Av. Augusto de Lima 1715, 30190-002 Belo Horizonte, MG, Brasil *Departamento de Zoologia, Instituto de Ciências Biológicas, UFMG, Belo Horizonte, MG, Brasil **Laboratório de Genética de Câncer, Instituto Ludwig de Pesquisas sobre o Câncer, São Paulo, SP, Brasil
\end{abstract}

The polymerase chain reaction and restriction fragment length polymorphism (RFLP) of the internal transcribed spacer(ITS) region of the rRNA gene, using the enzyme DdeI were used for the molecular identification of ten species and one subspecies of Brazilian Biomphalaria. Emphasis is given to the analysis of $\mathrm{B}$. oligoza, B. schrammi and $\mathrm{B}$. amazonica. The RFLP profiles obtained using this enzyme were highly distinctive for the majority of the species and exhibited low levels of intraspecific polymorphism among specimens from different regions of Brazil. However, B. peregrina and B. oligoza presented very similar profiles that complicated their identification at the molecular level and suggested a very close genetic similarity between the two species. Others enzymes including HaeIII, HpaII, AluI and $\mathrm{MnlI}$ were tested for their ability to differentiate these species. For B. amazonica three variant profiles produced with DdeI were observed. The study demonstrated that the ITS contains useful genetic markers for the identification of these snails

Key words: Biomphalaria - ribosomal DNA - internal transcribed spacer - polymerase chain reaction - Brazil

Ten species and one subspecies of Biomphalaria are recognized in Brazil: $B$. glabrata (Say, 1818), B. tenagophila (Orbigny, 1835), B. tenagophila guaibensis Paraense, 1984, B. straminea (Dunker, 1848), B. peregrina (Orbigny, 1835), B. kuhniana (Clessin 1883), B. schrammi (Crosse, 1864), B. amazonica Paraense 1966, $B$. oligoza Paraense, 1974, B. intermedia (Paraense $\&$ Deslandes, 1962) and B. occidentalis Paraense 1981. Only, B. straminea, B. t. tenagophila and B. glabrata are found naturally infected with Schistosoma mansoni. Among these, B. glabrata is the most important due to its wide spread distribution and its high susceptibility to $S$. mansoni (Paraense $\&$ Corrêa 1963). In addition B. peregrina and $B$. amazonica are considered potential hosts of this parasite based on experimental infection (Corrêa \& Paraense 1971, Paraense \& Corrêa 1973).

The morphological identification of freshwater snails of medical importance, is greatly complicated by the extensive intraspecific variation of the morphological characteristics used for classical identification (Paraense 1975, 1981, 1984,

Work partially supported by Fapemig and Pibic/Fiocruz. ${ }^{+}$Corresponding author. Fax: + 55-31-295.3115. E-mail: omar@cpqrr.fiocruz.br

Received 8 June 1999

Accepted 11 November 1999
1988). To overcome this problem, the use of molecular techniques as additional tools for the identification of these snails has been proposed. In previous studies we tested a low stringency polymerase chain reaction technique (LS-PCR) (Dias Neto et al. 1993) which permited the differentiation of B. glabrata and B. t. tenagophila and also the identification of very similar species such as B. t. tenagophila and B. occidentalis (Vidigal et al. 1996, Pires et al. 1997).

Recently, we have explored the possibility of using sequence polymorphism in the internal transcribed spacer region (ITS) of the rDNA of Biomphalaria snails (which includes the $5.8 \mathrm{~S}$ rDNA gene together with the flanking ITS1 and ITS2 spacers) by means of PCR amplification and digestion with different restriction enzymes. This method was successfully used to construct the molecular key for Aedes species (West et al. 1997). It was also used to distinguish closely related parasitic worms and others different organisms (Newton et al. 1998, Wu et al. 1999) and on studies of genetic variation and identification of snails of the genera Oncomelania, Bulinus and Biomphalaria (Hope \& McManus 1994, Stothard et al. 1996, Stothard \& Rollinson 1997, Rollinson et al. 1998, Vidigal et al. 1998a,b, Caldeira et al. 1998, Spatz et al. 1998, 1999).

The aim of the present study was to investigate the use of restriction profiles resulting from digestion of the ITS spacer of rDNA with Dde I for sepa- 
ration of the majority Biomphalaria species from Brazil, with special attention to $B$. oligoza, $B$. schrammi and $B$. amazonica species which were being studied for the first time. We found difficulty to differentiate between $B$. peregrina and $B$. oligoza with DdeI, however we propose the use of others restriction enzymes such as HpaII, Hae III and $A l u \mathrm{I}$ for identification of these species.

\section{MATERIALS AND METHODS}

Snail populations - Snail populations from different Brazilian localities were used (Fig. 1). The number of snails used and the geographical localization from each population are shown in the Table. The snails were identified by means of comparative morphology based on the reproductive organs and shells accordingly to Deslandes (1951) and Paraense (1975, 1981, 1984, 1988).

DNA extraction - Total DNA was extracted from the feet of snails using the Wizard Genomic DNA Purification Kit (Promega) with some modifications. Briefly, the tissues were mechanically disrupted in $200 \mu \mathrm{l}$ of nucleic lysis solution and incubated at $37^{\circ} \mathrm{C}$ for $4 \mathrm{~h}$ or overnight with $50 \mu \mathrm{g} /$ $\mathrm{ml}$ proteinase $\mathrm{K}$. Thereafter, $80 \mu \mathrm{l}$ of protein precipitation solution was added to the initial mix. The mixture was vortex vigorously for $10-20 \mathrm{sec}$ and centrifuged at 13,000 rpm for $5 \mathrm{~min}$. The supernatant was transferred to a microcentrifuge tube containing $200 \mu \mathrm{l}$ of room temperature isopropanol for DNA precipitation. The mixture was gently mixed by inversion for 20 min and centrifuged at $13,000 \mathrm{rpm}$ for $5 \mathrm{~min}$. The DNA pellet was washed with $300 \mu \mathrm{l}$ of $70 \%$ ethanol and centrifuged for 1 min. The pellet was treated with $25 \mu \mathrm{l}$ of DNA rehydration solution for $30 \mathrm{~min}$ at $65^{\circ} \mathrm{C}$ and stored at $-20^{\circ} \mathrm{C}$. The DNA concentrations were estimated by comparison with known standards on $2 \%$ ethidium bromide stained agarose gels.

Amplification by PCR - The entire ITS was amplified using the primers ETTS2 (5/TAACAAGGTTTCCGTAGGTGAA-3') and ETTS1 (5/-TGCTTAAGTTCAGCGGGT-3') anchored respectively in the conserved extremities of the $18 \mathrm{~S}$ and $28 \mathrm{~S}$ ribosomal genes (Kane \& Rollinson 1994). The PCR amplification was undertaken in a volume of $10 \mu \mathrm{l}$ consisting of: 1-10 ng template DNA, $10 \mathrm{mM}$ Tris- $\mathrm{HCl}, \mathrm{pH} 8.5,200$

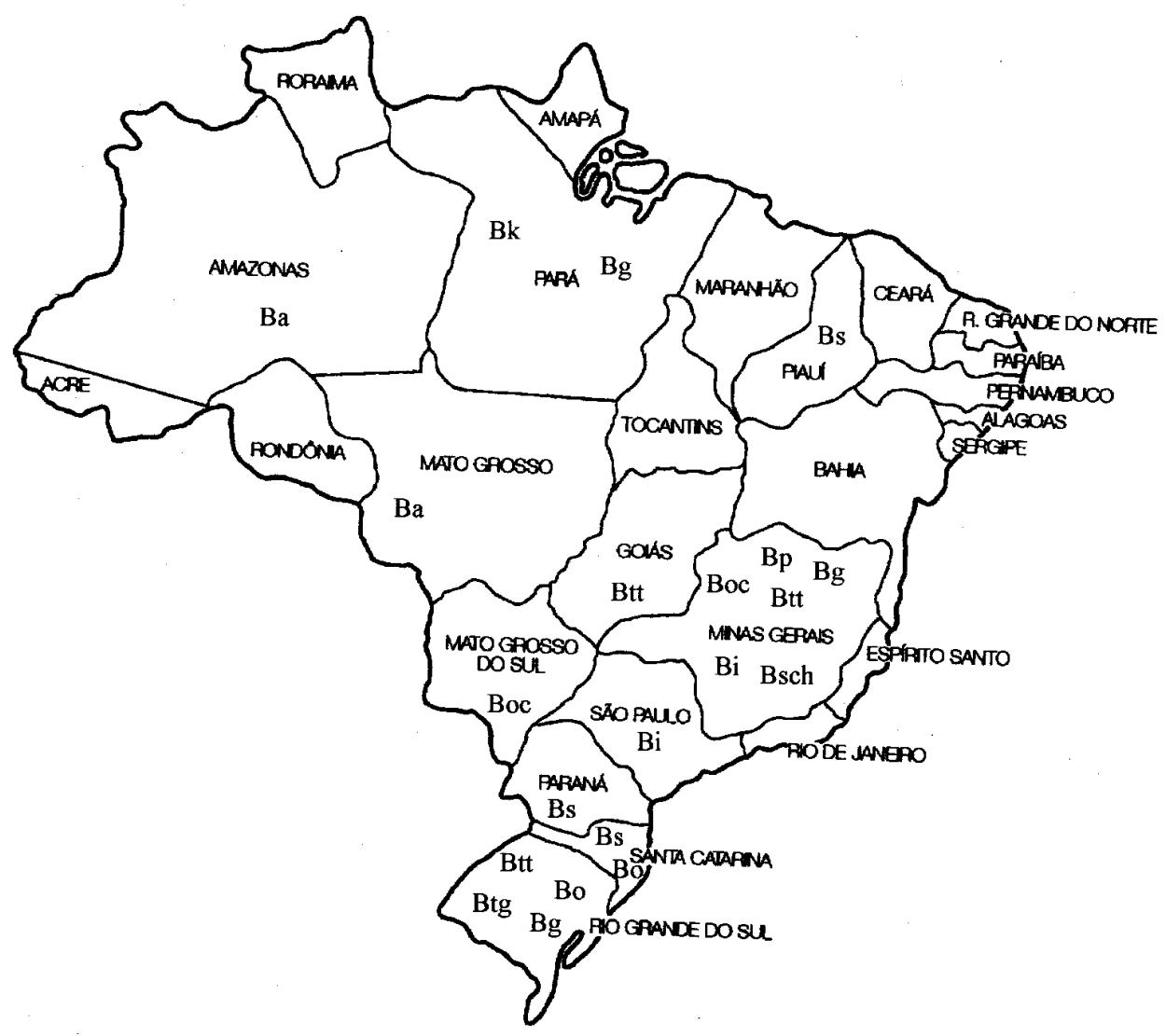

Fig. 1: map showing the localization of the snail populations used. The legend shows the abbreviation of each species mentioned in the map. Biomphalaria glabrata $(\mathrm{Bg}) ;$ B. tenagophila tenagophila $(\mathrm{Btt}) ;$ B. straminea $(\mathrm{Bs}) ;$ B. occidentalis $(\mathrm{Boc}) ;$ B. t. guaibensis (Btg); B. amazonica (Ba); B. intermedia (Bi); B. kuhniana (Bk); B. peregrina (Bp); B. oligoza (Bo); B. schrammi (Bsch). 
$\mu \mathrm{m}$ each dNTP, $1.5 \mathrm{mM} \mathrm{MgCl}_{2}, 0.8 \mathrm{U}$ of Taq DNA polymerase, $50 \mathrm{mM} \mathrm{KCl}$, together with 5.0 pmol of each primer. The reactions were covered with a drop of mineral oil and subjected to the following cycle program: initial denaturation step for $3 \mathrm{~min}$ at $95^{\circ} \mathrm{C}$, and then 32 cycles with annealling at $54^{\circ} \mathrm{C}$ for $1 \mathrm{~min}$, extension at $72^{\circ} \mathrm{C}$ for $2 \mathrm{~min}$, denaturation at $95^{\circ} \mathrm{C}$ for $45 \mathrm{sec}$ and a final extension step at $72^{\circ} \mathrm{C}$ for $5 \mathrm{~min}$. A negative control (no template DNA) was included in all experiments. Three microliters of the amplification products were visualised on $0.8 \%$ ethidium bromide stained agarose gels to check the quality of amplification. The remaining $7 \mu \mathrm{l}$ were mixed with $53 \mu \mathrm{l}$ of water, and divided into $10 \mu \mathrm{l}$ aliquots for enzyme digestion.

Production and evaluation of the rDNA-ITS RFLP profiles - In the initial experiments the enzyme DdeI (Amersham, Life Science) was evaluated for its ability to differentiate all Biomphalaria species from Brazil. Addicional enzymes were tested including AluI, MnII, (Amersham, Life Science) HaeIII and HpaII (Promega Co, USA) in situations when $D d e I$ was not effective in the separation of some species. One microliter (10-12 units) was used for each digestion reaction, together with $1.2 \mu \mathrm{l}$ of the respective enzyme buffer in a final volume of $12.2 \mu \mathrm{l}$. The digestion was performed for $3.5 \mathrm{~h}$ at $37^{\circ} \mathrm{C}$, and the digestion products were evaluated on 6 or $8 \%$ silver stained polyacrylamide gels (Sanguinetti et al. 1994) after phenol/ chlorophorm extraction. The results were recorded on Polaroid film 667 (St Albans, UK). A control for the activity of each enzyme was performed by digesting $150 \mathrm{ng}$ of pUC18.

\section{RESULTS}

The PCR amplification of the Biomphalaria ITS region with the primers ETTS2 and ETTS1 resulted in a product of approximately $1.3 \mathrm{~kb}$ (Fig. 2A). However, B. oligoza (lanes 18 and 19), $B$. peregrina (lanes 20 and 21 ) and $B$. amazonica (lanes 25 at 28) presented an ITS product of approximately $1.0 \mathrm{~kb}$. Fig. 2B shows the rDNA-ITS RFLP profiles produced by digestion with $D d e$ I of two to four specimens of all Biomphalaria species from Brazil. The profiles obtained with this enzyme permit the easy separation of the majority of the species analysed with exception of $B$. occidentalis and B. t. guaibensis (Fig. 2B lanes 7, 8 and 9,10, respectively) and B. oligoz $a$ and $B$. peregrina (Fig. 2B lanes 18, 19 and 20,21, respectively) which presented very similar profiles. The reproducibility of the profiles obtained with $D d e I$ for B. oligoza, B. peregrina, B. schrammi and $B$. amazonica were previously evaluated by increasing of the number of specimens for each spe- cies obtained from different localities (Table). Fig. 3 A shows the profiles obtained using $D d e$ I with $B$. oligoza collected in Rio Grande do Sul (lanes 1 to 4) and Santa Catarina (lanes 5 to 10). The profiles were very homogeneous for all specimens. Fig. 3B shows the profiles obtained for $B$. peregrina specimens collected from different localities in Minas Gerais. The profiles obtained with $B$. peregrina were homogeneous but, as mentioned above, similar to the those obtained from B. oligoza (Fig. 3A).

Fig. 4 shows the profiles of $B$. schrammi obtained with DdeI. This enzyme produced a simple profile with six fragments, which was clearly different from those seem with other species as observed in Fig. 2B (lanes 22 to 24). B. amazonica presented three variant profiles with three to nine fragments when treated with DdeI (Fig. 5). In fact in the snails from one locality (Benjamin Constant, Amazonas) three profiles were observed: lanes 1, 2 and 4 show the profiles characterized by presence of three bands, lane 3 shows five fragments and lanes 5, 6 and 7 show the profiles with nine fragments. In the snails obtained from Barão do Melgaço, Mato Grosso (lanes 8 to 10) only one profile with five fragments was observed. The specimens with variant profiles, for this species, were included in Fig. 2B (lanes 25 to 28). The profiles obtained with $D d e I$ for the ten species and one subspecies of the Brazilian Biomphalaria snails are represented in Fig. 6.

To obtain an improved molecular separation of $B$. oligoza and $B$. peregrina other enzymes were tested (HpaII, MnlI, AluI and HaeIII). Fig. 7A shows the results obtained with HpaII which produced the best results with distinct profiles observed for each species. Both HaeIII (Fig. 7B) and $A l u$ I (Fig. 7C) produced similar profiles with only subtle differences. B. oligoza and B. peregrina HaeIII profile shows six fragments two of which are species-specific for B. oligoza (Fig. 7B lanes 4 to 12). Using AluI B. peregrina presented one band of approximately $200 \mathrm{bp}$ distinct from B. oligoza (Fig. 7C). The enzyme MnlI did not permit the separation of these species (data not shown).

\section{DISCUSSION}

The possibility of using molecular tools for identification of snails of medical importance has contributed to increased knowledge of the genus Biomphalaria. Previously, we have explored other molecular methods to obtain species-specific markers. Initially we observed that the arbitrarily primed-PCR (AP-PCR) mirrored the high genetic variability in $B$. glabrata species (Vidigal et al. 1994, 1998b). These results demonstrated that this methodology does not provide good markers for molecular identification of Biomphalaria species. 

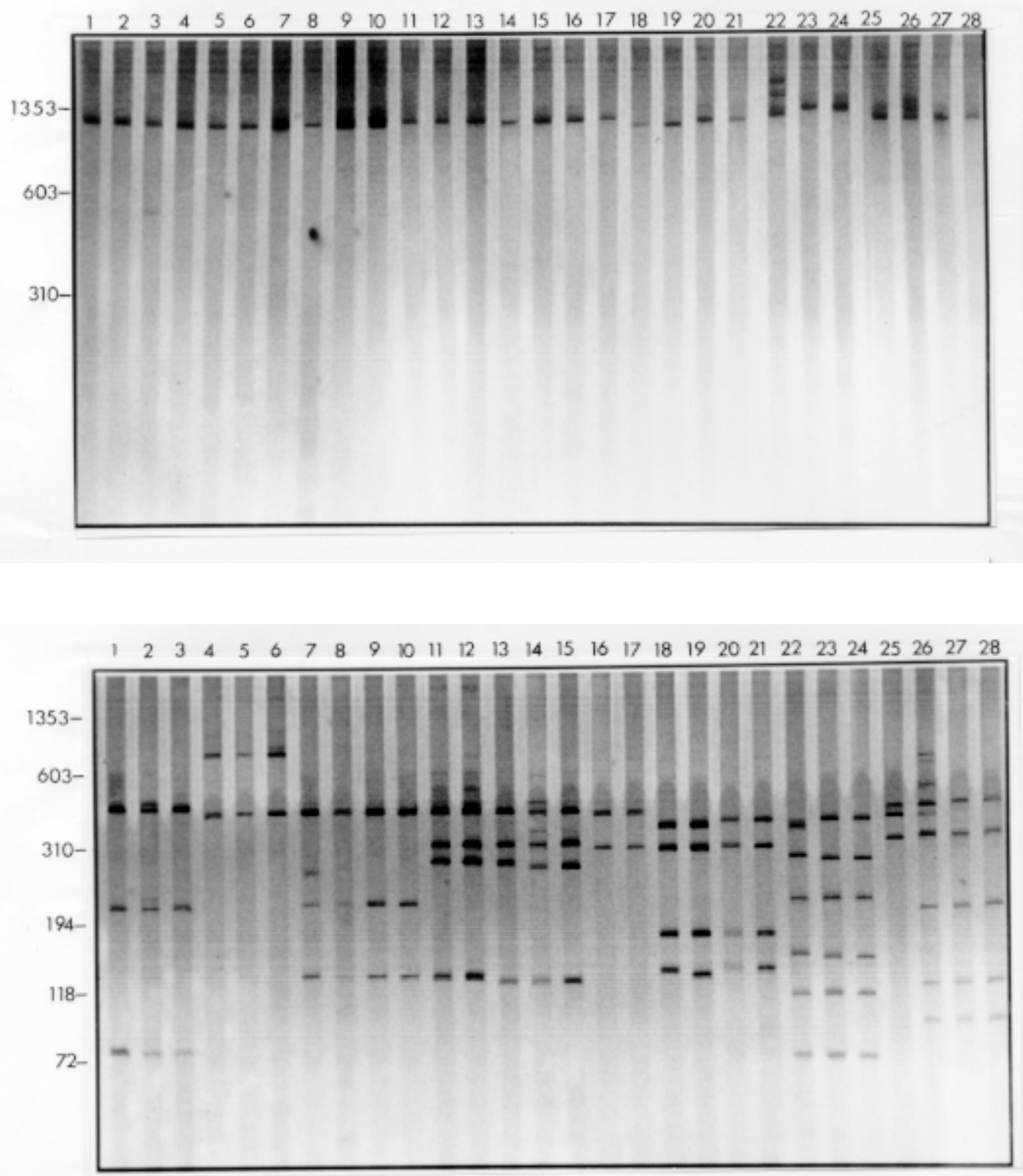

Fig. 2A: silver stained polyacrylamide gel $(6 \%)$ showing the products of polymerase chain reaction amplification of internal transcriber spacer (ITS) region of Biomphalaria species. Lane 1, B. glabrata from Belém, PA; lane 2, B. glabrata from, Sabará, MG; lane 3, B. glabrata from, Esteio, RS; lane 4, B. tenagophila from Formosa, GO; lane 5, B. tenagophila from Vespasiano, MG; lane 6, B. tenagophila from Imbé, RS; lane 7, B. occidentalis from Campo Grande, MS; lane 8, B. occidentalis from Capetinga, MG; lane 9, B. t. guaibensis from Esteio, RS; lane 10, B. t. guaibensis from Eldorado do Sul, RS; lanes 11 and 12, B. kuhniana from Tucuruí, PA; lane 13, B. straminea from Picos, PI; lane 14, B. straminea from Guaíra, PR; lane 15, B. straminea from Florianópolis,SC; lane $16, B$. intermedia from Itapagipe, MG; lane 17, B. intermedia from Pindorama, SP; lane 18, B. peregrina from Alfenas, MG; lane 19, B. peregrina from Bom Jesus da Penha, MG; lane 20, B. oligoza from Florianópolis, SC; lane 21 B. oligoza from Eldorado do Sul, RS; lane 22, B. schrammi from Itaú de Minas, MG; lane 23, B. schrammi from Cássia, MG; lane 24, B. schrammi from Ilicínea, MG; lanes 25 and 26, B. amazonica from Bejamin Constant, AM; lanes 27 and 28, B. amazonica from Barão de Melgaço, MT. Molecular size markers are shown on the left of each gel; B: silver stained polyacrylamide gel (8\%) showing the restriction fragment length polymorphism profiles obtained following digestion of rDNA ITS with DdeI. The legend is the same as that shown above. 
TABLE

Species, localities and localization of the populations of snails used

\begin{tabular}{|c|c|c|}
\hline Species & Localities (State) & Latitude/longitude \\
\hline \multirow[t]{3}{*}{ Biomphalaria glabrata } & Belém (Pará) & 01s27/48w30 \\
\hline & Esteio (Rio Grande do Sul) & $29 \mathrm{~s} 51 / 51 w 10$ \\
\hline & Sabará (Minas Gerais) & $19 \mathrm{~s} 53 / 43 w 48$ \\
\hline \multirow[t]{3}{*}{ B. tenagophila } & Vespasiano (Minas Gerais) & $19 s 41 / 43 w 55$ \\
\hline & Formosa (Goiás) $^{a}$ & $15 \mathrm{~s} 32 / 47 w 20$ \\
\hline & Imbé (Rio Grande do Sul) ${ }^{a}$ & $29 \mathrm{~s} 58 / 50 w 07$ \\
\hline \multirow[t]{3}{*}{ B. straminea } & Picos (Piauí) ${ }^{a}$ & $07 \mathrm{~s} 04 / 41 \mathrm{w} 28$ \\
\hline & Florianópolis (Santa Catarina) & $27 \mathrm{~s} 35 / 48 w 32$ \\
\hline & Guaíra (Paraná) $^{a}$ & $24 \mathrm{~s} 04 / 54 \mathrm{w} 15$ \\
\hline \multirow[t]{2}{*}{ B. intermedia } & Pindorama (São Paulo) & $21 \mathrm{~s} 11 / 48 w 54$ \\
\hline & Itapagipe (Minas Gerais) & $19 s 54 / 49 w 22$ \\
\hline \multirow[t]{4}{*}{ B. peregrina } & Alfenas (Minas Gerais) & $21 \mathrm{~s} 25 / 45 \mathrm{w} 56$ \\
\hline & Guimarânia (Minas Gerais) & $18 \mathrm{~s} 50 / 46 w 47$ \\
\hline & Juruaia (Minas Gerais) & $21 \mathrm{~s} 15 / 46 \mathrm{w} 34$ \\
\hline & Bom Jesus da Penha (Minas Gerais) & $21 \mathrm{~s} 01 / 46 w 31$ \\
\hline \multirow[t]{3}{*}{ B. schrammi } & Ilicínea (Minas Gerais) & $20 \mathrm{~s} 56 / 45 w 49$ \\
\hline & Itaú de Minas ( Minas Gerais) & $20 \mathrm{~s} 44 / 46 w 45$ \\
\hline & Cássia (Minas Gerais) & $20 s 34 / 46 w 55$ \\
\hline B. khuniana & Tucurui (Pará) & $03 \mathrm{~s} 46 / 49 w 40$ \\
\hline \multirow[t]{2}{*}{ B. occidentalis } & Capetinga (Minas Gerais) & $20 \mathrm{~s} 36 / 47 \mathrm{w} 03$ \\
\hline & Campo Grande (Mato Grosso do Sul) ${ }^{a}$ & $20 \mathrm{~s} 26 / 54 w 38$ \\
\hline \multirow[t]{2}{*}{ B.t. guaibensis } & Esteio (Rio Grande do Sul) & $29 \mathrm{~s} 51 / 51 \mathrm{w} 10$ \\
\hline & Eldorado do Sul (Rio Grande do Sul) & $30 \mathrm{~s} 05 / 51 w 36$ \\
\hline \multirow[t]{2}{*}{ B. oligoza } & Eldorado do Sul (Rio Grande Sul) & $30 \mathrm{~s} 05 / 51 \mathrm{w} 36$ \\
\hline & Florianópolis (Santa Catarina) & $27 \mathrm{~s} 35 / 48 w 32$ \\
\hline \multirow[t]{2}{*}{ B. amazonica } & Benjamin Constant (Amazonas) & 04s22/70w01 \\
\hline & Barão de Melgaço (Mato Grosso) ${ }^{a}$ & $16 \mathrm{~s} 11 / 55 \mathrm{w} 41$ \\
\hline
\end{tabular}

$a$ : laboratory populations

The LS-PCR technique produced a great number of bands complicating the identification of the species-specific LSP markers (LS products) (Vidigal et al. 1996, Pires et al. 1997). In the present study we demonstrate that PCR-RFLP of the ITS region of Biomphalaria rDNA, using DdeI, permits the differentiation of the majority of the ten Brazilian Biomphalaria species examined. In previous studies we demonstrated that restriction profiles resulting from digestion with $D d e$ I permit the identification of B. glabrata, B. straminea and $B$. tenagophila (Vidigal et al. 1998a,b). We also used this technique in the study of very similar species such as B. straminea, B. intermedia, B. kuhniana, $B$. peregrina (Caldeira et al. 1998) and B.t. tenagophila, B. t. guaibensis and B. occidentalis (Spatz et al. 1998, 1999).

The morphological separation of typical specimens of B. peregrina and B. oligoza are easy taste for the specialist in the identification of Biomphalaria snails. The principal characteristic for separation of these species is the presence of the small number of prostatic diverticula (1 to 6, rarely 7 ), or absence in B. oligoza (Paraense 1974, 1975). In $B$. peregrina the presence of 8 to 22 prostatic diverticula is reported. However, when specimens from both species show similar number of diverticula (B. oligoza maximum 7 and B. peregrina minimum 8) morphological separation of the species becomes more difficult. In this case only observation of the prostatic diverticula covering the spermathecal body of the B. peregrina can be considered as a diagnostic character (Paraense 1966, 1975). Here, the molecular results obtained with PCR-RFLP suggested a high similarity between these species based on the similarity of profiles obtained with DdeI and $A l u \mathrm{I}$ and the identical profiles produced with $M n l \mathrm{I}$. Although the similarity among these profiles, AluI, HpaII, HaeIII (7A, B, C) permit the molecular separation of these species and can be used in cases when the morphological identification of the B. oligoza and $B$. peregrina is not effective. It is noteworthy 

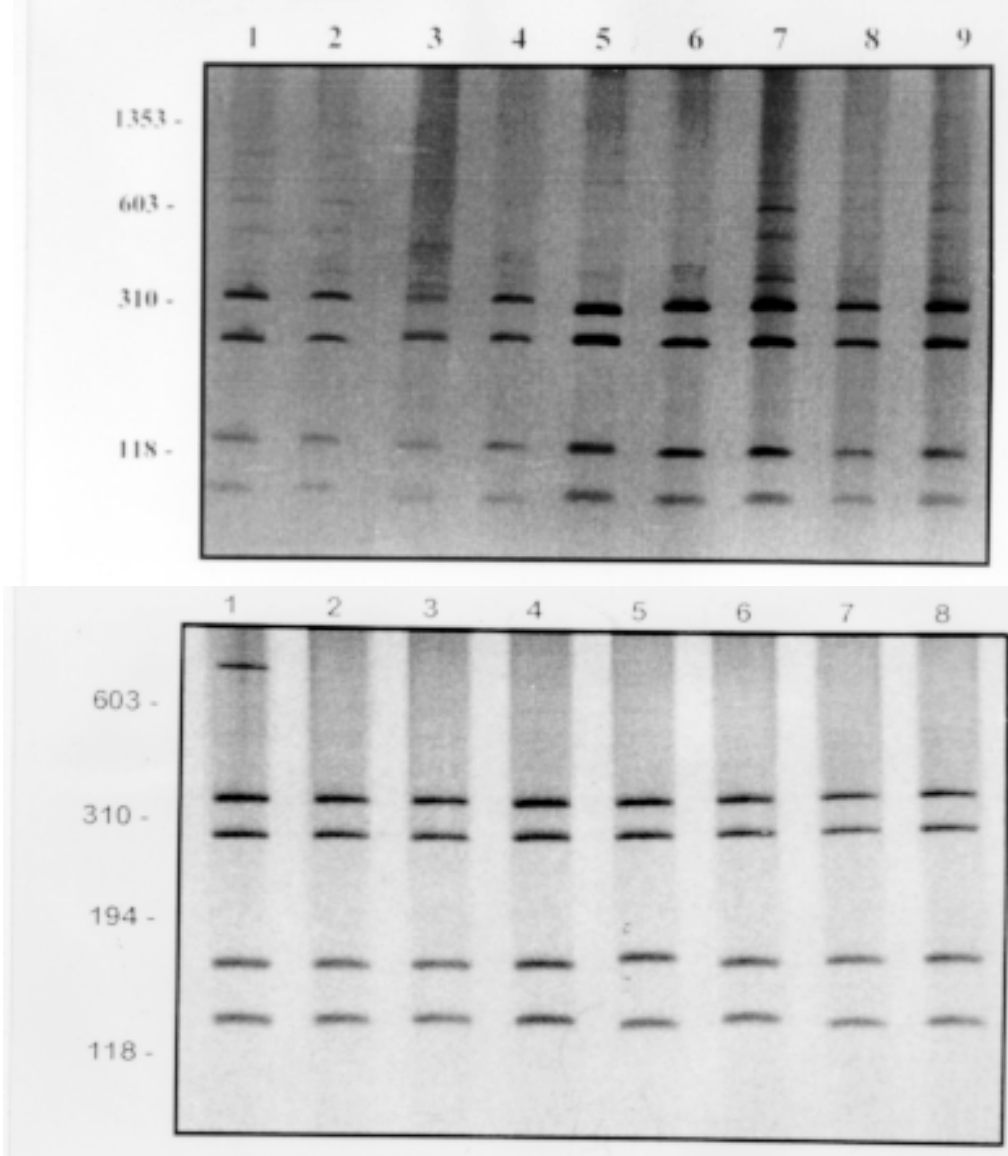

Fig. 3: silver stained polyacrylamide gel (8\%) showing restriction fragment length polymorphism profiles produced using $D d e$ I to digest rDNA internal transcriber spacer (ITS) amplified from specimens of Biomphalaria oligoza and B. peregrina from different localities in Brazil. A: B. oligoza: lanes 1 to 4, snails from Esteio, RS; lanes 5 to 10, snails from Florianópolis, SC; B: B. peregrina: lanes: 1 to 3 snails from Guimarânia, MG; lanes 4 to 6 snails from Alfenas, MG; lane 7, snail from Juruaia, MG; lane 8 snail from Bom Jesus da Penha, MG. Molecular size markers are shown on the left of each gel.

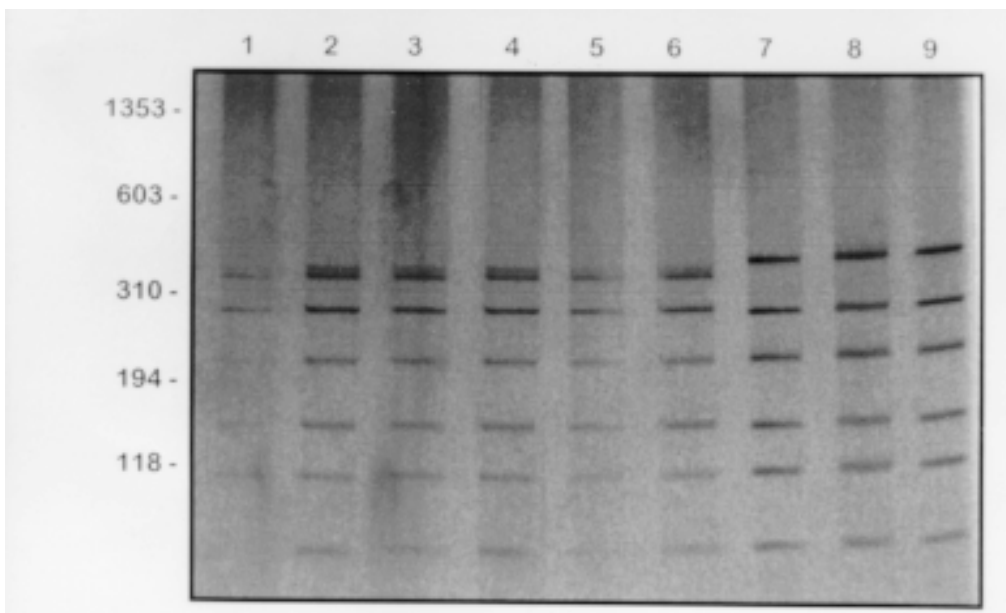

Fig. 4: silver stained polycrylamide gel (6\%) showing the restriction fragment length polymorphism profiles obtained by digestion of rDNA internal transcriber spacer (ITS) with DdeI. The DNA of individual snails of Biomphalaria schrammi obtained from: lanes 1 to 3, Cássia, MG; lanes 4 to 6, Itaú de Minas, MG; lanes 7 to 9, Ilicínea, MG. Molecular size markers are shown on the left of the gel. 


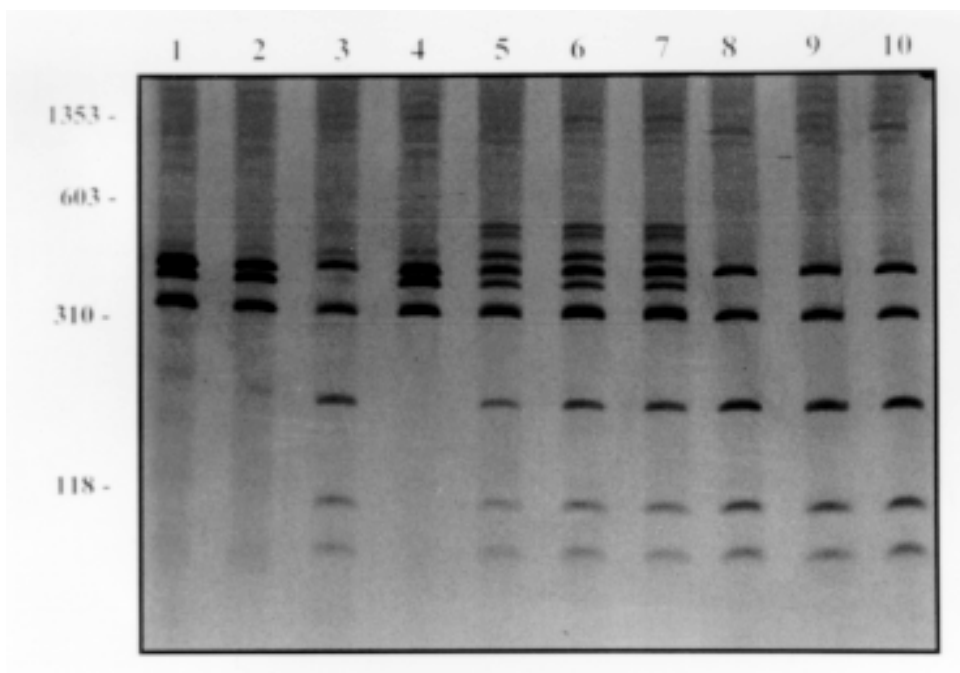

Fig. 5: silver stained polycrylamide gel (6\%) showing the restriction fragment length polymorphism profiles obtained by digestion of rDNA internal transcriber spacer (ITS) with DdeI. The DNA of individual snails of Biomphalaria amazonica obtained from lanes 1 to 7, snails from Benjamin Constant, AM and lanes 8 to 10, snails from Barão de Melgaço, MT. Molecular size markers are shown on the left of the gel.

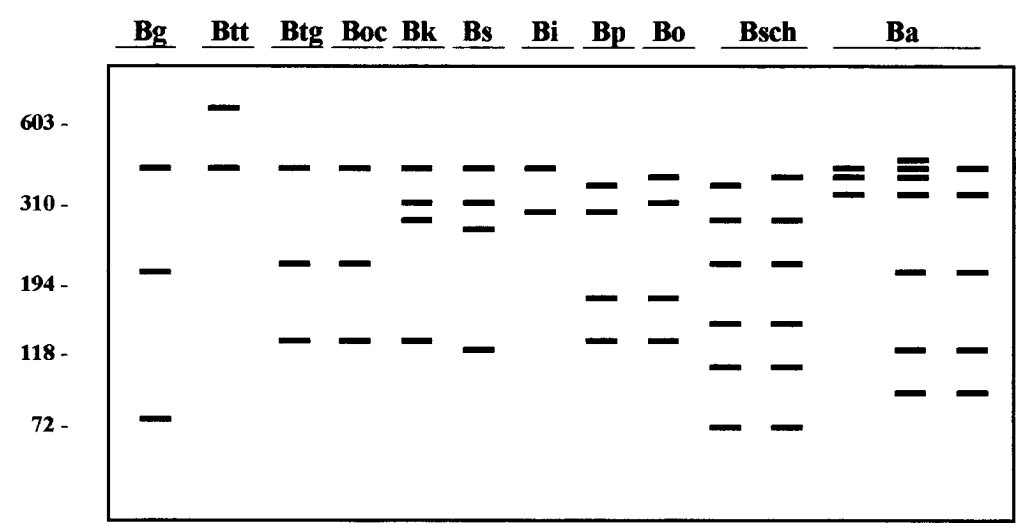

Fig. 6: schematic representation of the internal transcribed spacer rDNA restriction patterns of ten Brazilian Biomphalaria species and one subspecies produced with DdeI. The legend shows the abreviation of each species: Biomphalaria glabrata $(\mathrm{Bg}) ; B$. $t$. tenagophila $(\mathrm{Btt}) ;$ B. occidentalis $(\mathrm{Boc}) ;$ B. t. guaibensis $(\mathrm{Btg})$, B. straminea $(\mathrm{Bs}) ;$ B. intermedia $(\mathrm{Bi}) ;$ B. kuhniana $(\mathrm{Bk}) ;$ B. peregrina (Bp); B. oligoza (Bo); B. schrammi (Bsch) and B. amazonica (Ba). Molecular size markers are shown on the left of the gel.

that $B$. peregrina is one of the most widespread planorbid species in the Neotropical region hence, according to Paraense (1975), the origin to its scientific name (from the latin peregrinus, meaning wanderer, in reference to its wide geographical distribution).

B. schrammi is distributed in most regions of Brazil, but has not been found in Amazonas, Paraná, Rio Grande do Sul or Santa Catarina (Paraense 1975). The molecular characters shown here (Fig. 4) very clearly identified specimens belonging to this species. The distribution of $B$. amazonica in Brazil is concentrated in Amazonas,
Acre, Mato Grosso do Sul and Rondônia (Paraense 1983). The snails analyzed here were obtained from two distant localities and showed three variant profiles (Fig. 5). Accordingly the molecular identification of this species requires that attention is given to this diversity of profiles. The schematic representation of the ITS restriction patterns obtained for Brazilian Biomphalaria snails using DdeI can be used as model for comparative analysis (Fig. 6).

The sequences of ITS regions of the Brazilian Biomphalaria species will be analyzed in the future to better understand the intraspecific and interspecific relationships among this species. 

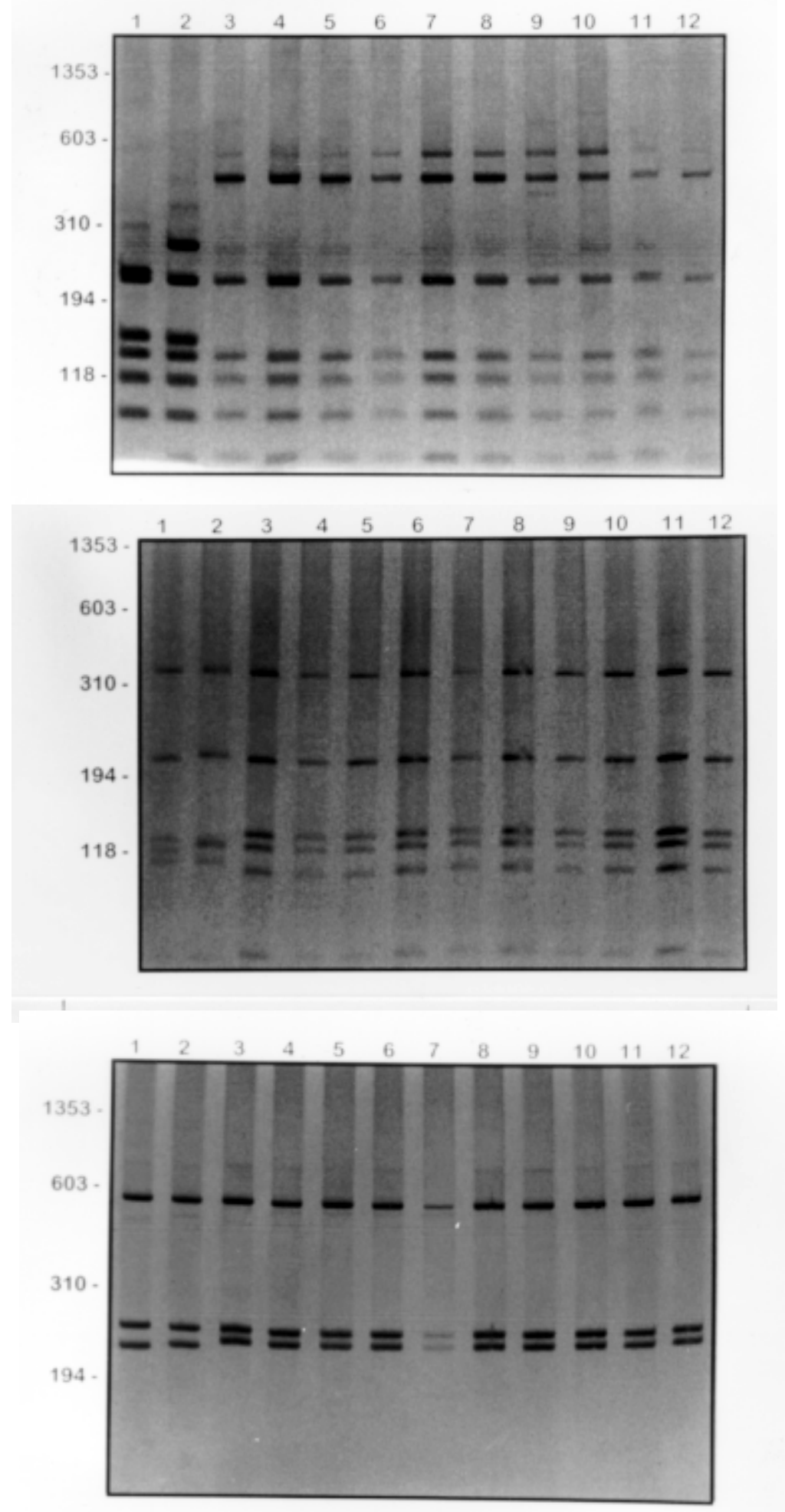

Fig. 7: (AluI) silver stained polycrylamide gel (6\% or $8 \%$ ) showing the restriction fragment length polymorphism profiles obtained following digestion of rDNA internal transcribed spacer with HpaII (A), HaeIII (B), AluI (C) amplified from DNA extracted from Biomphalaria peregrina and B. oligoza. In each gel the snails specimens are: lane 1, B. peregrina from Alfenas, MG; lane 2, $B$. peregrina from Bom Jesus da Penha, MG; lanes 3 at 7, B. oligoza from Eldorado do Sul, RS; lanes 8 at 12, B. oligoza from Florianópolis, SC. Molecular size markers are shown on the left of the gel. 
We show here that PCR-RFLP is a simple and rapid technique representing an important advance for studies of Brazilian Biomphalaria species which can be used as an auxiliary tool to morphological identification. The study demonstrated that ITS contains useful genetic markers for the identification of these snails. The results obtained with PCR-RFLP are concordant with the actual morphological systematics proposed for the Brazilian Biomphalaria snails by Paraense (1975, 1981, 1984, 1988).

\section{ACKNOWLEDGEMENTS}

To Dr Wladimir Lobato Paraense and Dr Ligia Corrêa from the Departamento de Malacologia, Instituto Oswaldo Cruz, for providing the snails. To Dr Mário Steindel from the Departamento de Parasitologia, UFSC, Santa Catarina, Andrea do Amaral Ferrari and Izabel Michelin Nunes from FNS, Porto Alegre, RS for technical support. To Yoná Rose Campos for assistance, and Letícia Peixoto Santos for administrative support.

\section{REFERENCES}

Caldeira RL, Vidigal THDA, Paulinelli ST, Simpson AJG, Carvalho OS 1998. Molecular identification of similar species of the genus Biomphalaria (Mollusca: Planorbidae) determined by a polymerase chain reaction-restriction fragment length polymorphism. Mem Inst Oswaldo Cruz, 93: 219-225.

Corrêa LR, Paraense WL 1971. Susceptibility of Biomphalaria amazonica to infection with two Brazilian strains of Schistosoma mansoni. Rev Inst Med Trop São Paulo 13: 387-390.

Deslandes N 1951. Técnica de dissecação e exame de planorbídeos. Rev Serv Espec Saúde Públ 4: 371382.

Dias Neto E, Santos FR, Pena SDJ, Simpson AJG 1993. Sex determination by Low Stringency PCR (LSPCR). Nucleic Ac Res 21: 763-764.

Hope M, McManus DP 1994. Genetic variations in geographically isolated populations and subspecies of Oncomelania hupensis determined by a PCR-based RFLP method. Acta Trop 57: 75-82.

Kane RA, Rollinson D 1994. Repetive sequences in the ribosomal DNA internal transcribed spacer of Schistosoma haematobium, Schistosoma intercalatum and Schistosoma mattheei. Mol Biochem Parasitol 63: 153-156.

Newton LA, Chilton NB, Beveridge I, Hoste H, Nansen P, Gasser RB 1998. Genetic markers for strongylid nematodes of livestock defined by PCR-based restriction analysis of spacer rDNA. Acta Trop 69: 115.

Paraense WL 1966. The sinonymy and distribution of Biomphalaria peregrina in the Neotropical region. Rev Bras Biol 26: 269-298.

Paraense WL, Corrêa, LR 1973. Susceptibility of Biomphalaria peregrina from Brazil and Ecuador to two strains of Schistosoma mansoni. Rev Inst Med Trop São Paulo 15: 127-130.

Paraene WL 1974. Biomphalaria oligoza N.N. for
Tropicobris philippianus (Dunker) sensu Lucena. Rev Brasil Biol 34: 379-386.

Paraense WL 1975. Estado atual da sistemática dos planorbídeos brasileiros. Arq Mus Nac Rio de Janeiro 55: $105-128$

Paraense WL 1981. Biomphalaria occidentalis sp.n. from South America (Mollusca Basommatophora Pulmonata). Mem Inst Oswaldo Cruz 76: 199-211.

Paraense WL 1983. A survey of planorbid molluscs in the Amazonian region of Brazil. Mem Inst Oswaldo Cruz 78: 343-361.

Paraense WL 1984. Biomphalaria tenagophila guaibensis ssp. n. from Southern Brazil and Uruguay (Pulmonata: Planorbidae). I. Morphology. Mem Inst Oswaldo Cruz, 79: 465-469.

Paraense WL 1988. Biomphalaria kuhniana (Clessin, 1883), planorbid mollusc from South America. Mem Inst Oswaldo Cruz 83: 1-12.

Paraense WL, Corrêa LR 1963. Variation in susceptibility of populations of Australorbis glabratus to a strain of Schistosoma mansoni. Rev Inst Med Trop São Paulo 5: 15-22.

Pires ER, Vidigal THDA, Teles HMS, Simpson AJG, Carvalho OS 1997. Specific identification of Biomphalaria tenagophila and Biomphalaria occidentalis populations by the Low Stringency Polymerase Chain Reaction. Mem Inst Oswaldo Cruz 92: 101-106.

Rollinson D, Stothard JR, Jones CS, Lockyer AN, Souza CP, Noble LR 1998. Molecular characterisation of intermediate snail host and the search for resistance genes. Mem Inst Oswaldo Cruz 93: 111-116.

Sanguinetti CJ, Dias Neto E, Simpson AJG 1994. Rapid silver staining and recovery of PCR products separated on polyacrylamide gels. Biotechniques 17:915918.

Spatz L, Vidigal THDA, Caldeira RL, Dias Neto E, Cappa SMG, Carvalho OS 1998. Molecular study of similar Biomphalaria species. Mem Inst Oswaldo Cruz, 93: 169-170.

Spatz L, Vidigal THDA, Caldeira RL, Dias Neto E, Cappa SMG, Carvalho OS 1999. Study of Biomphalaria tenagophila tenagophila, B. $t$. guaibensis and B. occidentalis by polymerase chain reaction amplification and restriction enzyme digestion of the ribosomal RNA intergenic spacer regions. J Moll Stud 65: 143-149.

Stothard JR, Hughes S, Rollinson D 1996. Variation within the internal transcribed spacer (ITS) of ribossomal DNA genes of intermediate snail hosts within the genus Bulinus (Gastropoda: Planorbidae). Acta Trop 61: 19-29.

Stohard JR, Rollinson D 1997. Molecular characterization of Bulinus globosus and B. nasutus on Zanzibar, and an investigation of their roles in the epidemiology of Schistosoma haematobium. Trans R Soc Trop Med Hyg 91: 353-357.

Vidigal THDA, Dias Neto E, Carvalho OS, Simpson AJG 1994. Biomphalaria glabrata: extensive genetic variation in Brazilian isolates revealed by random amplified polymorphic DNA analysis. Exp Parasitol 79: 187-194. 
Vidigal THDA, Dias Neto E, Simpson AJG, Carvalho OS 1996. A low stringency polymerase chain reaction approach to identification of Biomphalaria glabrata and Biomphalaria tenagophila intermediate snail hosts of Schistosoma mansoni in Brazil. Mem Inst Oswaldo Cruz 91: 739-744.

Vidigal THDA, Spatz L, Nunes ND, Simpson AJG, Carvalho OS, Dias Neto E 1998a. Biomphalaria sp: identification of the intermediate snail hosts of Schistosoma mansoni by polymerase chain reaction amplification and restriction enzyme digestion of the ribosomal RNA gene intergenic spacer. Exp Parasitol 89: 180-187.
Vidigal THDA, Dias Neto E, Spatz L, Nunes ND, Pires RE, Simpson AJG, Carvalho OS 1998b. Genetic variability and identification of the intermediate snail hosts of Schistosoma mansoni. Mem Inst Oswaldo Cruz 93: 103-110.

West DF, Payette T, Mundy T, Black IV WC 1997. Regional molecular genetic key of thirteen snow pool Aedes species (Diptera: Culicidae) in northern Colorado. J Med Entomol 34: 404-410.

Wu Z, Nagano I, Pozio E, Takahashi Y 1999. Polymerase chain reaction-restriction fragment length polymophism (PCR-RFLP) for the identification of Trichinella isolates. Parasitology 118: 211-218. 